\title{
IMPORTAÇÕES MEDITERRÂNEAS EM CONTEXTOS «Pós-Orientalizantes» do Sul de Portugal (SÉCULOS VI-IV A.N.E.)
}

Francisco B. Gomes

UNIARQ - Centro de Arqueologia da Universidade de Lisboa; FCT

Recibido: 21/01/2014

Revisado: $12 / 02 / 2014$
Aceptado: $18 / 03 / 2014$

Publicado: 20/05/2014

\section{RESUMEN}

Nos contextos da Idade do Ferro do interior do território baixo alentejano documenta-se um número considerável de elementos de importação relacionáveis com as redes de comércio mediterrâneas, presentes quer em contextos domésticos quer funerários, quer ainda religiosos. A análise destes elementos - amuletos egípcios, adornos de cornalina e pasta vítrea, recipientes de perfumes em cerâmica e vidro, cerâmicas gregas e contentores anfóricos - a partir de uma perspectiva contextual permite definir e caracterizar pautas de consumo diferenciadas que apontam para uma utilização destes elementos exógenos no quadro de práticas sociais de âmbito local.

\section{Palavras Chave}

Idade do Ferro «Pós-Orientalizante»; Baixo Alentejo; Importações mediterrâneas; Consumo; Comensalidade.
ABSTRAC

In the Iron Age contexts of the interior of the Lower Alentejo region a considerable number of imported elements has been documented which can be related to the Mediterranean commercial networks, and which are present both in domestic and funerary contexts, as well as in religious ones. The analysis of such elements - Egyptian amulets, carnelian and glass adornments, perfume containers both ceramic and in glass, Greek pottery and amphorae - from a contextual perspective permits to define and characterize the differentiated consumption patterns which point to the use of this exogenous elements in the frame of local social practices.

\section{KEYWORDS}

«Post-Orientalizing» Iron Age; Lower Alentejo; Mediterranean imports; Consumption; Commensality. 


\section{Em toRno AO CONCEITO DE «Pós-ORIENTALI-} ZANTE»

No contexto recente da produção científica sobre a Idade do Ferro no território meridional português o designativo "Pós-Orientalizante» tem conhecido uma considerável difusão (cf. Jiménez Ávila, 2008a), tendo-se vindo a aplicar sobretudo às entidades arqueológicas do interior do território alentejano que apresentam, no quadro do desenvolvimento histórico regional ao longo do I milénio a.n.e., uma marcada identidade própria.

É sabido que a génese deste conceito deve procurar-se no contexto do estudo arqueológico da sequência cultural sidérica no território da actual Extremadura (Almagro Gorbea, 1977, 507), e em particular do Guadiana Médio, onde se vem utilizando para designar um horizonte cultural caracterizado pela emergência de peculiares fenómenos de ocupação dispersa do território, materializados quer em complexos monumentais de cariz socialmente destacado (Jiménez Ávila, 1997) quer em outras tipologias de povoamento aberto (Jiménez Ávila \& Ortega Blanco, 2008); estas novas modalidades de ocupação do espaço entendem-se como resultado de uma profunda restruturação sociopolítica na sequência do final do horizonte propriamente «Orientalizante» regional (Almagro Gorbea, 1977; Celestino Pérez, 1995; 2005).

No caso extremeño, e abdicando aqui de comentar extensivamente a discussão em torno à efectiva operacionalidade das periodizações que se têm manejado e aos conteúdos culturais, sociais, políticos e mesmo territoriais daquelas (cf. Celestino Pérez, 2008), a utilização do designativo «Pós-Orientalizante» alia de forma mais ou menos clara, do ponto de vista semântico, dois significados particulares: por um lado, um significado estritamente cronológico, ainda recentemente reivindicado (Jiménez Avila, 2008a, 102), e expresso pelo antefixo "pós" que estabelece a posterioridade cronológica e a sequencialidade assumida em relação ao Período Orientalizante contribuindo assim para balizar temporalmente um determinado fenómeno histórico; por outro, um significado sociocultural, servindo para designar uma fase de marcada regionalização, em que a área do Guadiana Médio adquire do ponto de vista arqueológico, não obstante a presença de correlatos evidentes de comércio de larga distância (Jiménez Ávila, 2007), uma identidade própria muito vincada (Jiménez Ávila, 2008b, 279).
Este conceito operativo, primeiramente aplicado, como disse, dentro de um determinado quadro territorial, foi depois importado para a leitura de realidades do actual território português (Arruda, 2001; cf. tb. Arruda, 2005a, 294), tendo sido utilizado para designar um amplo conjunto de sítios do interior alentejano, nomeadamente da área de Ourique (Beirão, 1986; Correia, 1993) e de Castro Verde (Maia \& Maia, 1986; 1996), que configuram eles próprios, tanto quanto os dados disponíveis permitem afirmar, uma rede de povoamento formada por pequenos núcleos dispersos no território, onde as influências orientais/orientalizantes parecem ter chegado tardiamente e de forma muito mais difusa do que sucedeu noutros sítios do litoral, onde se detectou um horizonte considerado propriamente «Orientalizante» (Arruda, 1999-2000; 2005a; 2005b).

A aplicação a este conjunto de sítios do designativo "Pós-Orientalizante» resulta em parte, pareceme, de uma certa similitude detectável entre estes sítios e os seus congéneres "extremeños", tanto no que diz respeito a determinados aspectos da cultura material como no respeitante à própria solução de ocupação do território que materializam (Arruda, 2001, 281).

A partir dessa introdução, o conceito tem-se vindo a aplicar com frequência para designar contextos que, como veremos, se revestem de características muito diversificadas (p. ex., Calado \& Mataloto, 2008; Antunes, 2010; Soares, 2012; cf. tb. Jiménez Ávila, 2008a). Existem, contudo, como foi sempre devidamente notado (Arruda, 2001, 283; Mataloto, 2008, 220-221) diferenças de escala e de complexidade material relativa entre uma e outra área regional que sugerem situações sociopolíticas apesar de tudo bastante diferenciadas.

Mas existe outra diferença substancial que me parece importante realçar: se no caso do Vale Médio do Guadiana espanhol o que os autores que procuraram definir a natureza desse horizonte «Pós-Orientalizante» sugerem ter-se verificado é, fundamentalmente, uma regionalização, resultante da desestruturação da koiné «Orientalizante», no caso do Baixo Alentejo o conteúdo cultural, chamemos-lhe assim, desse horizonte é outro; nesse território as evidências de uma presença propriamente "Orientalizante» são virtualmente nulos (Arruda, 2001; Fabião, 2001; Mataloto, 2008, 221), verificando-se isso sim uma interpenetração de elementos materiais e culturais mediterrâneos, 
tardiamente introduzidos e sempre com um peso relativamente reduzido, e de elementos de tradição eminentemente local, muitos dos quais com protótipos no Bronze Final local/regional (Arruda, 2005a; Mataloto, 2009).

Estamos assim perante aquilo a que se chamou já um «Pós-Orientalizante que nunca o foi» (Mataloto, 2008), o que levanta a questão da pertinência da aplicação deste conceito para as realidades em apreço. Com efeito, se existe, como vimos, uma coerência interna na sua aplicação à periodização sidérica no território extremeño (concorde-se ou não, repito, com essa periodização), no caso do interior português - onde as evidências de um horizonte cultural «Orientalizante» estão virtualmente ausentes e onde, em momento ainda a precisar do século VI a.n.e., se consolida um horizonte arqueológico essencialmente original, marcado, repita-se, pela complexa interacção de tradições e práticas locais com elementos culturais e materiais exógenos - a aplicação desse designativo perde efectivamente boa parte da sua eficácia terminológica.

O progresso da investigação e a descoberta, tornada constante nos últimos anos, de novos sítios e contextos permite, além disso, levantar a questão da própria diversidade do horizonte dito «Pós-Orientalizante», com marcados individualismos sub-regionais/locais - contraste-se, por exemplo, a região de Ourique (Beirão, 1986; Correia, 1993; Arruda, 2001) ou de Castro Verde (Maia \& Maia, 1986; 1996) com a do Regolfo do Alqueva (Mataloto, 2004; 2008; 2009; Calado, Mataloto \& Rocha, 2007; Calado \& Mataloto, 2008), a de Moura (Soares, 2012) ou com as recentemente identificadas necrópoles da área de Beja (Santos et al., 2009; Salvador Mateos \& Pereira, 2012; Arruda et al., no prelo) -, individualismos esses cujo significado (territorial? cronológico? cultural?) não é ainda fácil precisar.

O panorama da investigação recente permite, assim, uma deslocação do foco interpretativo, que deve afastar-se cada vez mais de um entendimento do horizonte dito «Pós-Orientalizante» como realidade periférica com respeito aos círculos de ampla e profunda interacção promovidos, a partir de inícios do I milénio a.n.e., pela colonização e o comércio fenícios, espécie de "Epi-Orientalizante» à margem do processo geral de transformação cultural expressivamente atestado pelos sítios «Orientalizantes» do litoral (Arruda, 1999-2000).

As futuras leituras que se venham a desenvolver sobre este mundo sidérico do interior alente- jano devem, com efeito, aprofundar a exploração dos processos que conduziram à emergência deste horizonte cultural e avaliar de forma cada vez mais específica a possibilidade de que a aparência de conservadorismo destes contextos interiores possa representar, de facto, uma estratégia social e identitária, de representação, na sequência de um rápido (e violento) reajustamento das redes sociopolíticas locais, na transição do Bronze Final para a I Idade do Ferro (Mataloto, 2012; Gomes, no prelo a).

A diversidade sub-regional a que antes aludi sugeriria, pois, a existência de um processo diferenciado de aquisição, manipulação e adaptação de traços materiais e culturais exógenos, inscritos sempre contudo, tudo o sugere, no quadro de práticas sociais eminentemente locais. Uma análise dos elementos a que pode atribuir-se uma origem mediterrânea e uma leitura contextual dos mesmos pode, além de sugerir pautas de consumo específicas e diferenciadas, permitir entrever alguns dos mecanismos subjacentes a essas lógicas de apropriação.

2. IMPORTAÇÕES MEDITERRÂNEAS: UM QUADRO SINTÉTICO.

\subsection{Nota prévia}

O levantamento de elementos de importação mediterrânea identificados em contextos sidéricos do interior do território meridional português (Fig. 1) que seguidamente se apresenta constitui uma base para uma primeira abordagem sistemática às putativas pautas de consumo que regeram a incorporação dessas importações nos regimes de valor e nas práticas sociais locais. Reveste-se, contudo, de limitações metodológicas que devem desde já ser assumidas e contempladas.

Desde logo, torna-se necessário notar que nem todos os contextos analisados foram objecto de publicação com o mesmo grau de profundidade e de exaustividade. Em muitos casos as observações que seguidamente tecerei podem vir a ser frontalmente contrariadas por futuros estudos aprofundados de conjuntos até agora apenas parcialmente publicados; noutros casos, o enquadramento contextual preciso das peças analisadas é desconhecido, forçando a considerar apenas um enquadramento funcional lato, extrapolado da interpretação global disponível para o sítio em que se identificaram.

Outra questão que não pode obviar-se prendese com a delimitação exacta do que são - e do que não são - elementos de importação. Não podemos, 


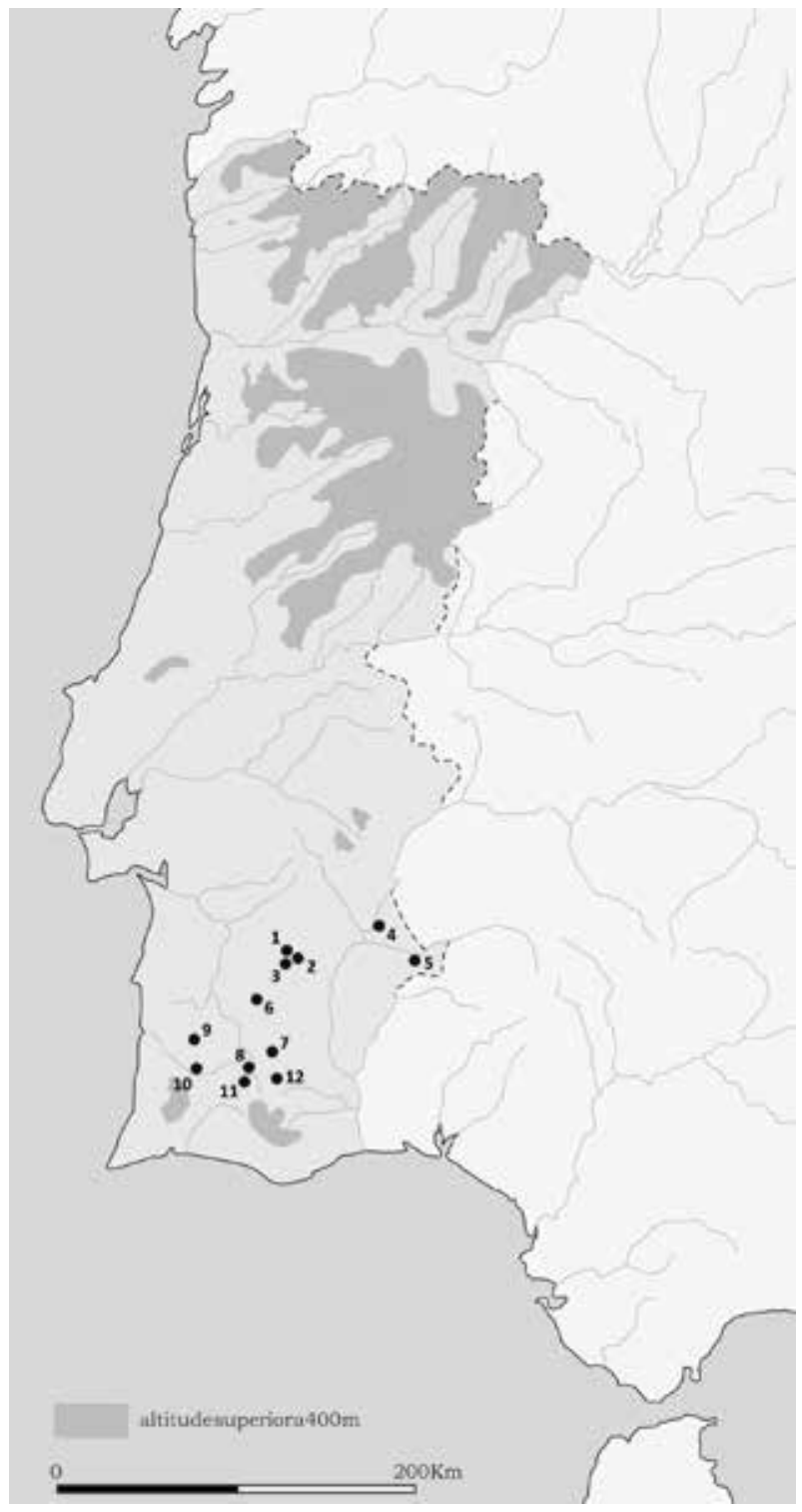

Figura 1. Sítios com materiais analisados no texto (localizações aproximadas): 1 - Vinha das Caliças 4; 2 Palhais; 3 - Carlota; 4 - Azougada; 5 - Cabeço Redondo; 6 - Côrte Margarida; 7 - Núcleo de Neves-Corvo (Neves I, Neves II, Corvo I); 8 - Núcleo de Ourique-Aldeia de Palheiros (necrópoles de Fernão Vaz, Mealha Nova, Fonte Santa, Favela Nova e Chada e povoado de Fernão Vaz); 9 - Pardieiro; 10 - Nora Velha; 11 - Herdade do Pêgo; 12 - Monte Beirão. (Base cartográfica do Professor Doutor Vítor S. Gonçalves).

com efeito, e no estado actual dos nossos conhecimentos, excluir que existam outros materiais (penso, sobretudo, nos elementos de indumentária e na joalharia) que possam ter sido objecto de comércio a distâncias relativamente longas; não podemos, igualmente, excluir para outros elementos (penso, desta feita, na pasta vítrea e nos adornos de cornalina) a existência de centros produtores mais próximos, ainda não identificados nem caracterizados (cf., para o caso da cornalina, Gonçalves \& Soares, 2010; Gonçalves et al., 2011).

Ocupar-me-ei nas seguintes linhas de peças a que com forte probabilidade se pode atribuir uma origem forânea, mediterrânea ou, pelo menos, nas costas meridionais peninsulares, e que seguramente respondem, isso sim, a modelos exógenos, o que não impede que futuras abordagens, sobretudo de índole analítica, possam alterar o quadro aqui traçado.

Outra restrição, desta feita voluntária, diz respeito ao escopo geográfico da análise - centrar-me -ei nos contextos enquadráveis numa porção concreta do território meridional português, o Baixo Alentejo (integrando o actual Distrito de Beja e parte do de Setúbal), excluindo assim alguns contextos contemporâneos do Alentejo Central e do Alto Alentejo, onde se documentaram importações mediterrâneas, que serão evocadas mas não analisadas em pormenor.

Tive já oportunidade de mencionar aquilo que me parece ser a crescente desadequação do termo "Pós-Orientalizante» como descritor das realidades sidéricas do interior alentejano; a selecção, neste trabalho, de um conjunto de sítios passíveis de integrar esse horizonte reveste-se também, pois, de um cariz eminentemente problemático.

O problema da periodização da Idade do Ferro do Sul do território português volta actualmente a colocar-se à luz da acumulação de novos achados, que acentuam a tendência já de há muito assinalada (Arruda, 2001) de complexificação do mosaico cultural sidérico nesse território, tornando fluídos - demasiado fluídos - os limites entre horizontes culturais. Incluí, pois, nesta análise sítios com naturezas muito diferenciadas, mas que partilham uma implantação interior, características (aparentemente) rurais e uma adopção muito seleccionada de elementos forâneos, profundamente imbricados em conjuntos materiais de matriz endógena e em práticas sociais que podemos, em geral, considerar como locais.

O quadro cronológico da análise decorre organicamente dessa selecção, abarcando um período compreendido grosso modo entre os meados do século VI e as primeiras décadas do IV a.n.e. dentro do qual se distribuem as ocupações dos sítios analisados (cf. Arruda, 2001; 2005a). 
Não pretendo com este artigo negar, nem tão - pouco mascarar as evidências crescentes de uma diversidade sub-regional, subscrevendo de resto a necessidade de avançar, cada vez mais, com leituras de âmbito micro-espacial, local, para melhor aferir tanto das especificidades idiossincráticas de cada sítio ou grupo de sítios como das regularidades transversais que decorrem da sua inscrição em redes e esferas de interacção progressivamente mais amplas. Serve contudo esta análise, volto a sublinhar, como uma primeira e preliminar abordagem à problemática da adopção dos elementos materiais e dos estímulos culturais dessas esferas mais amplas no quadro de discursos e práticas de ordem local/ regional.

2.2. Amuletos egipcios/egiptizantes (Fig. 2)

Conhece-se no Sul do actual território português um conjunto substancial de escaravelhos/escarabóides de tipo egípcio provenientes de contextos da Idade do Ferro (Almagro Gorbea \& Torres Ortiz, 2009), dos quais um número significativo provém de contextos ditos "Pós-Orientalizantes» do interior, em particular do território baixo-alentejano.

$\mathrm{Na}$ região de Ourique/Vale do Mira (Beirão, 1986; Correia, 1993; Arruda, 2001) este tipo de ele- mentos são relativamente frequentes, tendo-se exumado exemplares nas necrópoles da Mealha Nova (Palheiros, Ourique) - um escaravelho engastado em anel giratório com inscrição de Petubastis, considerado como procedente de Náucratis e datado entre finais do século VII e finais do VI a.n.e. -, da Fonte Santa (Ribeira do Sado, Ourique) - um exemplar com inscrição hieroglífica, considerado de produção fenícia e proveniente de um contexto datado do século $\mathrm{V}$ a.n.e., e restos de uma segunda peça, muito deteriorada, engastada em anel de prata -, da Favela Nova (Ourique) - um escarabóide de bronze, pseudo-egípcio, produzido em atelier indeterminado e datado dos séculos VI-V a.n.e. - e do Pardieiro (S. Martinho das Amoreiras, Odemira) - onde se exumou um anel com estojo para um escaravelho/escarabóide, não conservado (Almagro Gorbea \& Torres Ortiz, 2009, com bibliografia).

Devido à virtual ausência de restos humanos preservados nas necrópoles da região, todas estas peças carecem de certos elementos contextuais caracterizadores, nomeadamente no que diz respeito às pautas demográficas de distribuição deste tipo de peça. Note-se, não obstante, o seu enquadramento exclusivo em contextos funerários.

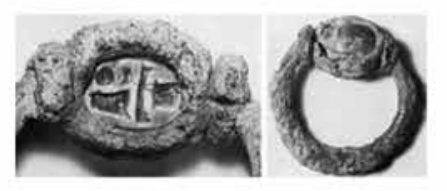

1

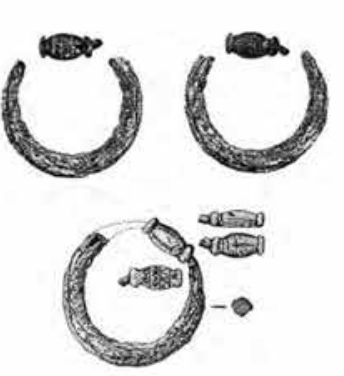

2

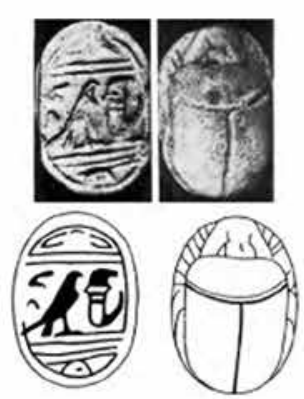

3

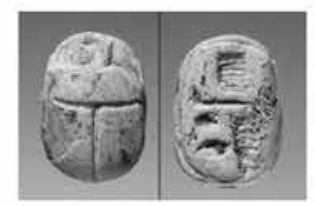

4

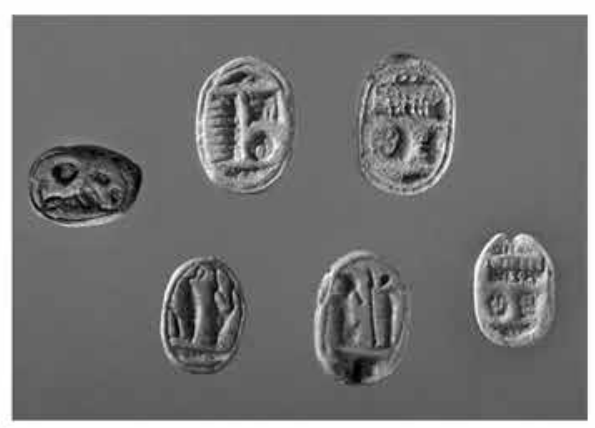

5

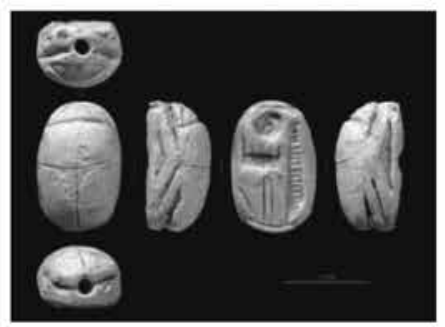

6

Figura 2. Amuletos (escaravelhos/escarabóides) de tipo egípcio: 1 - Mealha Nova; 2 - Favela Nova; 3 - Fonte Santa; 4 - Côrte Margarida (todos seg. Almagro Gorbea \& Torres Ortiz, 2009, com bibliografia); 5 - Vinha das Caliças 4 (seg. Arruda et al., no prelo); 6 - Palhais (seg. Santos et al., 2009). 
De igual modo, os exemplares mais recentemente exumados de Côrte Margarida (Aljustrel), da Vinha das Caliças 4 e de Palhais (Beja) integravam espólios funerários. No primeiro caso um escaravelho aparentemente de pasta branca com inscrição de Petubastis, eventualmente uma produção de Náucratis, foi exumado numa sepultura em cista; a cronologia geral deste conjunto funerário, apenas muito parcialmente escavado, centra-se entre meados do século VI e finais do V a.n.e. (Deus \& Correia, 2005; Almagro Gorbea \& Torres Ortiz, 2009, 526-527). Também neste caso não se exumaram restos antropológicos passíveis de indiciar pautas mais específicas de utilização.

Mais dados a esse respeito proporcionam os seis exemplares exumados na necrópole da Vinha das Caliças 4 - cinco escaravelhos e um escarabóide -, ainda em processo de estudo. Estas peças foram exumadas numa sepultura de inumação feminina enquadrada num recinto rectangular delimitado por um fosso, que reforça a imagem de excepcionalidade desta deposição, que continha um espólio funerário destacado, incluindo peças de ourivesaria e abundantes contas de pasta vítrea (Arruda et al., no prelo). Trata-se, muito provavelmente, de produções de Naucrátis e podem, com base na cronologia global do conjunto funerário, datar-se da segunda metade do século VI a.n.e. (ibidem).

Finalmente, da necrópole de Palhais procede um escaravelho de pedra branca (Santos et al., 2009, Fig. 8) ostentando na base uma inscrição com o

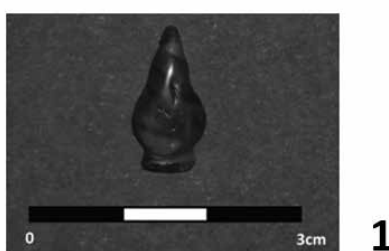

1

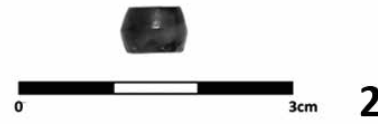

2

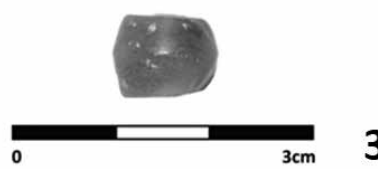

Figura 3. Peças em cornalina: 1 a 3 - Vinha das Caliças 4 (seg. Arruda et al., no prelo); 4 - Pardieiro (seg. Beirão, 1990). teónimo Amon-Ré em signos hieroglíficos, tendose considerado uma produção «...do Império Novo ou posterior (séculos XVI-VIII a.C.)...» (Almeida \& Araújo, 2009, 119). Pode aventar-se, sem certeza contudo, uma produção egípcia para esta peça. Os dados antropológicos associados permitem afirmar que, tal como no caso da Vinha das Caliças, a peça de Palhais provém de uma sepultura feminina, estando acompanhado por elementos de indumentária e instrumentos cosméticos que apontam para o seu elevado estatuto (Santos et al., 2009, 763-770). Para a referida sepultura, designada Sepultura 2, propôs-se uma cronologia do século VI a.n.e. (idem: 768-769).

2,3. Contas/pendentes de cornalina (Fig. 3)

Outros elementos que podem com relativa segurança adscrever-se à esfera do comércio de larga distância mediterrânea são as peças de cornalina que, apesar de incomuns, se têm vindo a exumar em vários contextos ditos "Pós-Orientalizantes» no Sul de Portugal. Com efeito, os estudos que se têm dedicado a este tipo de peças, que aparecem com certa profusão a partir do Bronze Final (Martín de la Cruz, 2004), apontam para a inexistência de jazidas de cornalina na Península Ibérica (Martín de la Cruz et al., 2005, 508), podendo sugerir-se uma eventual procedência egípcia para a matéria-prima utilizada nos exemplares difundidos pelo Mediterrâneo a partir da segunda metade do II milénio a.n.e. (Martín de la Cruz et al., 2005, 508).

A presença de peças realizadas nesta matéria-prima encontra precedentes no Bronze Final regional, com destaque para o conjunto de treze contas do Castro dos Ratinhos (Moura) (Gonçalves \& Soares, 2010), a que se somam exemplares provenientes do povoado do Álamo (Moura) e de Salsa 3 (Serpa) (Gonçalves et al., 2011) ou ainda do Monte do Outeiro 2 (Reguengos de Monsaraz), já no Alentejo Central, onde se exumou um pendente em forma de romã ou de papoila (Mataloto, 2012, Fig. 23).

Idêntica a esse exemplar é uma outra peça, desta feita de cronologia plenamente sidérica, exumada na já referida necrópole da Vinha das Caliças, na mesma sepultura de onde provém o conjunto de escaravelhos antes comentado (cf. supra). Existem, na mesma necrópole, duas outras peças de cornalina, correspondendo neste caso a contas de colar de morfologia bitroncocónica, ambas provenientes igualmente de sepulturas femininas. A cronologia geral destas peças pode situar-se, por analogia com a datação proposta para este conjunto funerário, na 
segunda metade do século VI a.n.e. (Arruda et al., no prelo).

Outros exemplares de elementos de adorno de cornalina concentram-se, uma vez mais, nas necrópoles da região de Ourique/Vale do Mira, com atestações na também já mencionada necrópole da Fonte Santa - duas contas de colar, uma das quais oblonga, associadas aos escaravelhos comentados supra (Beirão, 1986, 71) -, na da Mealha Nova - uma conta de colar «...em forma de 'bago de romã'... (Dias, Beirão \& Coelho, 1970, 178), não ilustrada -, e na do Pardieiro - um pendente oblongo (Beirão, 1990). A cronologia de conjunto destes elementos pode estabelecer-se, com base nas datações dos respectivos contextos e da sequência dos monumentos tumulares de Ourique, em momentos entre meados/finais do século VI a.n.e. e os finais da centúria seguinte (cf. Arruda, 2001).

Para estes casos, e pelas razões antes comentadas a propósito dos amuletos de tipo egípcio, não dispomos de dados finos para caracterizar o contexto social de uso destas peças, devendo contudo sublinhar-se novamente a sua estrita adscrição ao mundo funerário.

\subsection{Contas de colar de pasta vítrea}

Ainda no respeitante aos elementos de adorno, é de referir a presença frequente e abundante de conjuntos de contas de colar de pasta vítrea, cobrindo um amplo espectro tipológico, formal e decorativo, tendo estas sido já consideradas como um dos elementos mais característicos dos espólios funerários «Pós-Orientalizantes» no Sudoeste Peninsular (Jiménez Ávila, 2002-2003, 89-90).

Abordar com detalhe os conjuntos de peças desta natureza presentes no território meridional português resultaria num excurso demasiado extenso relativamente à natureza e objecto desta contribuição; com efeito, as contas de colar vítreas são virtualmente ubíquas nos contextos que se enquadram no horizonte que vimos comentando, estando presentes em sítios com naturezas e funções muito diferenciadas, de natureza doméstica, religiosa e funerária.

Não obstante, e tanto quanto os dados disponíveis permitem afirmar, existem diferenças quantitativas muito assinaláveis, correspondendo os exemplares exumados em sítios de habitat (p. ex., em Fernão Vaz, Ourique, cf. Beirão, 1986; Correia \& Parreira, 2002, 42) a casos virtualmente isolados e numericamente residuais, ao passo que nos contextos funerários se documentam, em muitos casos, acumulações significativas, de que o conjun- to da Vinha das Caliças 4, ascendendo a quase oito centenas de registos - contabilizou-se um número mínimo de 794 exemplares (Arruda et al., no prelo; Gomes, no prelo b) - constitui um exemplo extremo, tanto pela quantidade como pela diversidade tipológica e pela raridade e originalidade de alguns dos tipos documentados (idem).

Como tive oportunidade de assinalar recentemente (Gomes, no prelo b), as peças vítreas da Vinha das Caliças 4 revestem-se de um interesse adicional por possibilitarem, graças aos relevantes dados antropológicos obtidos durante a escavação, uma primeira aproximação às pautas sociais de utilização destes objectos, tendo-se documentado uma utilização diferenciada dos mesmos - um terço das sepulturas não continha objectos vítreos, e dentro dos restantes dois terços nota-se a existência de acumulações consideráveis em sepulturas de indivíduos concretos, cujos espólios em geral e, nalguns casos, a implantação destacada dentro do conjunto da necrópole sugerem um estatuto social elevado.

Os dados sugerem, de resto, que um dos factores dessa diferenciação poderá ter sido o género, não existindo qualquer caso de associação de contas de pasta vítrea a indivíduos masculinos; $59 \%$ dos exemplares estão claramente associados a indivíduos femininos, $6 \%$ a indivíduos infantis e os restantes 35\% exumaram-se em sepulturas em que não se obtiveram indicações quanto ao sexo do inumado (idem).

Sem pretensões de exaustão, podemos elencar alguns outros conjuntos significativos exumados em contextos pertinentes para esta análise: o da necrópole de Fernão Vaz, Ourique (Correia, 1993), os das já mencionadas necrópoles de Fonte Santa (Beirão, 1986), Favela Nova (Dias \& Coelho, 1983), Pardieiro (Beirão, 1990), Mealha Nova (Dias, Beirão \& Coelho, 1970) ou Herdade do Pêgo (idem), o da Chada, Ourique (Beirão, 1986), o da Nora Velha (Arnaud, Martins \& Ramos, 1994; Soares, 2013), todos sítios da área de Ourique/Vale do Mira, o da necrópole de Côrte Margarida, Aljustrel (Deus \& Correia, 2005), o da necrópole de Palhais, Beja (Santos et al., 2009) ou o praticamente desconhecido conjunto da Azougada, Moura (Gomes, 1990, 40).

Muito menos expressivos são, aparentemente, e em linha com o que ficou dito acima, os conjuntos exumados em sítios domésticos e/ou religiosos como Fernão Vaz, Ourique (Correia \& Parreira, 2002, 42), ou Neves I (Maia, 1987, 237) e Corvo I (Maia \& Correa, 1985, 253), ambos em Castro Verde. 
Já fora do território mais imediatamente aqui analisado, deve mencionar-se a presença, ainda que aparentemente residual, de contas de pasta vítrea na necrópole da Têra, Alandroal, já no Alentejo Central (Rocha, Duarte \& Pinheiro, 2005, Fig. 5), ou o excepcional conjunto da Cabeça de Vaiamonte, Monforte, no Alto Alentejo (Fabião, 2001). Este último, ainda que pareça constituir uma excepção ao panorama antes traçado, com um volumoso conjunto de 1644 contas exumado num sítio de habitat, enferma contudo de sérios problemas contextuais derivados da bem conhecida história das intervenções no sítio, não podendo portanto aferirse com exactidão qual seria o contexto social de uso das peças ali exumadas.

Note-se que, embora não disponhamos em muitos casos de datações seguras para muitos dos contextos referidos, o arco cronológico que permitem desenhar para a chegada e utilização destes elementos de adorno em pasta vítrea abarca pelo menos a segunda metade do século VI e todo o século V a.n.e., permitindo recuar a cronologia destes elementos face a propostas recentes que os colocariam preferencialmente nos séculos V-IV a.n.e. (Jiménez Ávila, 2004, 107).

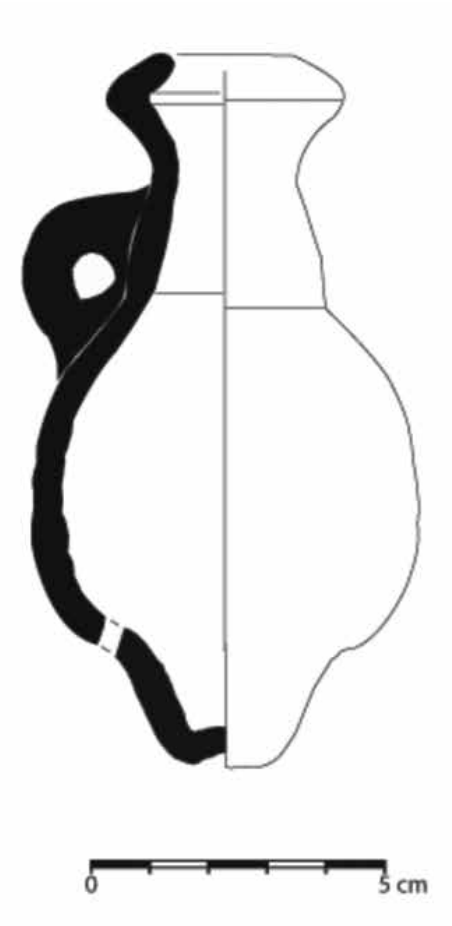

1

\subsection{Unguentários/alabastra de pasta ví-} trea

Ainda no domínio dos elementos de pasta vítrea deve assinalar-se a importação de recipientes, unguentários e/ou alabastra, que são contudo incomuns nos sítios do interior alentejano. No território baixo-alentejano, com efeito, documentaram-se peças deste tipo apenas no sítio de Corvo I, Castro Verde (Maia \& Maia, 1986, 13; Maia \& Maia, 1996, 88), em número infelizmente indeterminado devido, suponho, ao seu estado de fragmentação. Os fragmentos exumados foram classificados como pertencendo a "...anforiscos ou alabastra de pasta de vidro polícroma, formando padrões de espinhado a branco, amarelo e verde sobre fundo azul escuro..." e considerados "...claros produtos de origem Leste-mediterrânea» (Maia \& Maia, 1996, 88).

O seu contexto funcional é problemático mas, como sugerem algumas evidências recentemente dadas à estampa (Maia, 2008, 359-361) e como já se sugeriu em diversas ocasiões (Arruda \& Celestino Pérez, 2009, 37-38; Gomes, 2012, 78-82), o sítio de Corvo I poderá corresponder a um complexo religioso, o que forneceria um enquadramento funcional geral para as peças em questão.

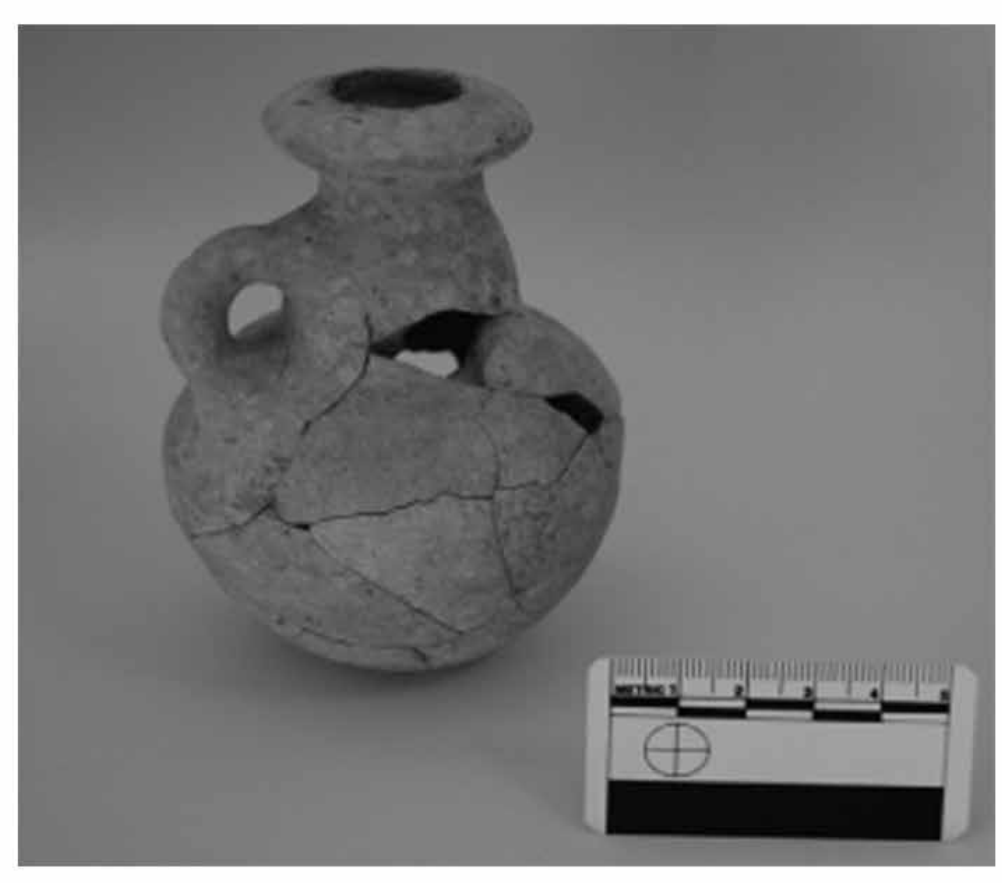

2

Figura 4. Oil Bottles: 1 - Palhais (seg. Santos et al., 2009); 2 - Carlota (seg. Salvador Mateos \& Pereira, 2012). 
A importação destes exemplares baixo-alentejanos (a que se somam outros melhor conservados de contextos litorais, como da necrópole da Herdade do Gaio, cf. Arruda, 1999-2000, 97) deve de resto contextualizar-se com a presença de peças congéneres em outros contextos interiores, tanto no Alentejo Central - caso das peças da necrópole da Têra (Rocha, Duarte \& Pinheiro, 2005, Fig.4; Mataloto, 2010-2011, 92 e Fig. 8) ou do habitat da Malhada das Taliscas (Calado, Mataloto \& Rocha, 2007, 156) - como no Alto Alentejo, nomeadamente na Cabeça de Vaiamonte (Fabião, 2001, 212 e Fig. 11).

A baliza cronológica usualmente admitida para este tipo de peças centra-se, sobretudo, no século V a.n.e. (cf. Jiménez Ávila, 1999, 149), datação genérica que convém à maioria dos contextos referidos.

2.6. Oil bottles de tipo fenício (Fig. 4)

Ainda no domínio dos recipientes de transporte de óleos e perfumes deve referenciar-se o achado recente de dois exemplares cerâmicos enquadráveis na forma geralmente designada como "oil bottle" ou ampolla, de clara tradição oriental e estreitamente relacionada, na bacia do Mediterrâneo, com o comércio fenício (Orsingher, 2010).

Ambas as peças provêm de contextos funerários recentemente escavados na área de Beja; um exemplar foi exumado na já mencionada necrópole de Palhais (Santos et al., 2009, 776-777 e Fig. 15) e o outro na necrópole da Carlota (Salvador Mateos \& Pereira, 2012, 322 e Fig. 15). Ambos apresentam características formais que os aproximam das séries de finais do século VII ou inícios do VI a.n.e. (Orsingher, 2010), devendo quiçá privilegiar-se, dadas as cronologias de conjunto das respectivas necrópoles, uma cronologia dentro desta última centúria.

Esta forma cerâmica é bastante invulgar nos contextos sidéricos do território português (Gomes, no prelo c) e a adição destes novos exemplares, que alargam ao interior a geografia da sua distribuição, constituem uma interessante evidência da expansão do consumo de essências e perfumes na Idade do Ferro que, como já se referiu (idem) e voltaremos a ver adiante, segue pautas sociais muito específicas.

\subsection{Cerâmica grega (Fig. 5)}

A expansão do comércio de produtos gregos, em particular da cerâmica ática, na área atlântica da Península Ibérica a partir do século V a.C. (cf. Arruda, 1997; 2006) tocou também o interior alentejano, estando referenciada a presença de peças com aquela proveniência em diversos contextos enquadrados no horizonte dito «Pós-Orientalizante». Assim, do- cumentaram-se fragmentos de cerâmica de verniz negro em Fernão Vaz, Ourique (dois fragmentos, Beirão, 1986, 114; Beirão \& Correia, 1991, 10), em Neves I (dez fragmentos, Maia, 1987, 237 e Lám. XI), em Neves II (um fragmento, Maia \& Correa, 1985, 248), e em Corvo I (Maia \& Maia, 1996, 88), Castro Verde, e no Cabeço Redondo, Moura (Soares, 2012, 77-78); todos estes exemplares correspondem a Taças Cástulo com cronologias da segunda metade do século $\mathrm{V}$ - inícios do IV a.n.e..

Já na Azougada, Moura, cujo conjunto de cerâmica grega continua a ser deficientemente conhecido (cf. Arruda, 1997, 91, com bibliografia) documentaram-se tanto taças deste mesmo tipo como taças de figuras vermelhas, enquadráveis já na primeira metade do século IV a.n.e.; deve de resto salientar-se a natureza excepcional deste sítio implantado directamente sobre o Guadiana, para o qual se pode propor uma natureza eminentemente religiosa (Arruda \& Celestino Pérez, 2009, 38; Antunes, 2009; Gomes, 2012, 59-66) e que terá desempenhado um papel de relevo na articulação das redes comerciais regionais (Antunes, 2010).

Deve, por fim, referenciar-se a existência de um contentor anfórico de produção grega, caso único no actual território português, recolhido à superfície no sítio de habitat de Monte Beirão, Almodôvar (Beirão, 1986, 51 e Fig. 7A), de provável produção Sâmia, enquadrável no Tipo $\mathrm{N}$ do naufrágio de $\mathrm{El}$ Sec (Arribas et al., 1987), datada da primeira metade do século IV a.n.e. (Arruda, 1997, 93).

Numa análise preliminar podem notar-se várias especificidades das pautas de importação da cerâmica grega no interior baixo-alentejano. Desde logo, deve assinalar-se a relativa exiguidade dos conjuntos conhecidos quando comparados aos de núcleos litorais ou sub-litorais contemporâneos, como Castro Marim (Arruda, 1997), Mértola (Arruda, Barros \& Lopes, 1998) ou Alcácer do Sal (Rouillard et al., 1988-1989).

Em segundo lugar, note-se a relativa monotonia dos repertórios, dominados por recipientes destinados ao consumo de líquidos, as Taças Cástulo, a que se junta um contentor anfórico relacionado com a importação de vinho, o que configura um horizonte funcional muito específico. Deve, em relação com este último apontamento, salientar-se também o seu enquadramento exclusivo em ambientes domésticos - salvo no caso da Azougada onde, contudo, podem relacionar-se com o putativo ascendente comercial do sítio - e a sua total ausência em con- 
textos funerários, contrastando com a situação contemporânea no litoral, por exemplo no Olival do Senhor dos Mártires (Rouillard et al., 1988-1989) e também com a situação posterior documentada em sítios como o Cerro Furado, Beja (Arruda, 2006, 138) ou a Quinta da Queimada, Lagos (Calado \& Gomes, 2006).

\section{8. Ânforas (Fig. 5)}

Para lá da ânfora grega antes comentada, a importação de produtos alimentares envasados em contentores anfóricos de tipologias próprias, sobretudo, da Baixa Andaluzia apontam também para a incorporação, em quantidades sempre aparentemente reduzidas, de produtos exógenos.

Ânforas de importação estão atestadas no provável complexo religioso de Neves I, Castro Verde, onde se exumou um número indeterminado de ânforas de que se ilustrou um exemplar (Maia, 1987, 237 e Lám. XI) do Tipo B/C de Pellicer (1978). Em Neves II, Castro Verde, um espaço de habitat com características de excepção, exumaram-se também ânforas forâneas, incluindo um exemplar da família das Mañá-Pascual A4, e mais concretamente do Tipo 11.2.1.3 de Ramon Torres (1995), de provável produção gaditana, bem como outros exemplares cujo enquadramento tipológico é difícil precisar (Maia, 1988, Est. VII); entre estes, alguns (idem, nn. 1 e 2) poderão corresponder a produções regionais do Vale do Guadiana, assimiláveis ao Tipo I de Cancho Roano (Guerrero Ayuso, 1991), pelo que não deverão considerar-se importações strictu sensu, ao passo que outro exemplar (Maia, 1988, Est. VII, n. 3) não pode por agora classificar-se com segurança.

Quanto a Corvo I, Castro Verde, não possuímos qualquer informação além de referências à presença de ânforas ditas púnicas e consideradas de tipos evolucionados, mas nunca especificados (Maia, 1987, 36). Também no sítio de habitat do Cabeço Redondo, Moura, se identificaram fragmentos anfóricos de produção exógena, oriundos da Baixa Andaluzia, não se tendo contudo exumado elementos passíveis de classificação tipológica (Soares, 2012, 75-76).

A cronologia das poucas peças seguramente classificáveis dentro deste panorama sugere cronologias centradas sobretudo no século $\mathrm{V}$ a.n.e., facto reforçado pela aparente associação contextual de alguns destes exemplares anfóricos às já referidas Taças Cástulo (Maia, 1987, 237). Não é fácil, por outro lado, precisar os conteúdos destes recipientes anfóricos, muitos dos quais são inclusivamente, como se disse, de difícil enquadramento tipológico. Não deixa de ser digna de nota, contudo, e uma vez mais, a sua aparente escassez e a sua presença exclusiva em contextos domésticos e/ou religiosos, reforçando a impressão já antes sugerida de integração dos respectivos conteúdos em práticas de consumo muito específicas, com conotações sociais igualmente vincadas.

3. UMA APROXIMAÇÃo ÀS PAUTAS DE CONSUMO DAS IMPORTAÇÕES MEDITERRÂNEAS NO INTERIOR BAIXO -ALENTEJANO

\subsection{Breves considerações sobre cronologias} e ritmos de importação

Como já por diversas vezes foi mencionado, os diversos sítios que se têm vindo a relacionar com o horizonte dito "Pós-Orientalizante» e sobre os quais versa a presente análise constituem, na verdade, uma realidade marcadamente heterogénea, cuja diversidade parece responder a diversos factores, cronológicos, geográficos mas também funcionais e, porventura, socioculturais.

Não é este o momento para abordar a complexa interligação entre todos estes factores, tarefa que os dados actualmente disponíveis, de resto, talvez ainda não autorizem. Impõem-se, não obstante, algumas considerações sobre a distribuição cronológica das importações atestadas como forma de melhor situar historicamente as lógicas do seu consumo.

Com efeito, verificam-se significativos desfasamentos entre os intervalos de importação e circulação de cada uma das classes de importações antes resenhadas que importa salientar, até para melhor dar conta do dinamismo interno do horizonte cultural a que me venho referindo.

Assim, deve assumir-se uma cronologia porventura mais recuada, logo a partir dos meados do século VI a.n.e. para alguns dos elementos de importação. É o caso, seguramente, das oil bottles, forma que praticamente desaparece no último quartel daquela centúria (Orsingher, 2010); os invulgares exemplares do interior alentejano não possuem paralelos exactos, no entanto poderiam mesmo evocar cronologias ainda mais recuadas, dos inícios/ primeira metade do século VI a.n.e..

O caso dos amuletos egipcíos/egiptizantes é mais complexo, pois sabemos que existem por vezes importantes intervalos entre a sua produção e a sua amortização; não obstante, e pelos contextos em que se têm exumado, os primeiros exemplares de peças deste tipo, nomeadamente os das necró- 
poles de Palhais e da Vinha das Caliças 4, poderão remontar também à segunda metade do século VI a.n.e.. Os contextos exactos dos exemplares da área de Ourique são, apesar de tudo, menos expressivos, mas não é improvável que estes elementos continuem a depositar-se em contextos funerários ao longo do século $\mathrm{V}$ a.n.e..

Mais problemática é a questão da cronologia das contas de pasta vítrea, tendo-se proposto nos últimos anos que a importação em massa desses elementos é própria já do século $\mathrm{V}$ e dos inícios do IV a.n.e. (Jiménez Ávila, 1999). Os dados obtidos na Vinha das Caliças, cuja ocupação não ultrapassa os primeiros anos do século $\mathrm{V}$ a.n.e., sendo a grande maioria das sepulturas datável da segunda metade da centúria anterior (Arruda et al., no prelo), e onde se exumou, como se disse, um dos mais expressivos conjuntos de contas de pasta vítrea do Sudoeste peninsular (idem; Gomes, no prelo b), parece contrariar esta cronologia baixa, recuando assim a chegada em massa destes elementos pelo menos para os meados do século VI a.n.e..

Seguramente já ao século $V$ a.n.e. deverão adscrever-se, isso sim, os parcos exemplares de unguentá- rios/anforiscos em pasta vítrea (cf. Jiménez Ávila, 2003: 267), que atestam a continuidade da procura de perfumes e substâncias aromáticas para lá do fim da circulação das "oil bottles" de tipo fenício.

Também àquela centúria e aos inícios da seguinte se devem atribuir as importações gregas, quer as cerâmicas áticas de verniz negro como, e de forma mais restrita, de figuras vermelhas; a solitária ânfora grega de Monte Beirão corresponde, também ela, a um horizonte da primeira metade do século IV a.n.e. (Arruda, 1997; 2006).

As cronologias dos restantes contentores anfóricos importados situam-se também no século V a.n.e.. É esta a datação geralmente aceite para o Tipo 11.2.1.3 de Ramon Torres (1995, 235; cf. tb. Sáez Romero, 2008, 529-530), atestado como ficou dito em Neves II. No caso do exemplar do Tipo B/C de Pellicer de Neves I, a sua datação é algo mais dilatada, recobrindo aquela forma cronologias que se estendem dos meados/finais do século VI ao século III a.n.e. (Pellicer, 1978; cf. tb. Belén, 2006); o seu horizonte cronológico específico pode ser algo restringido pela sua aparente associação a exemplares de Taças Cástulo (Maia, 1987, 237), que datariam o
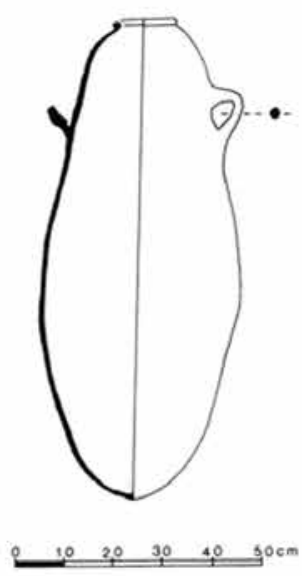

1

\section{(1)}

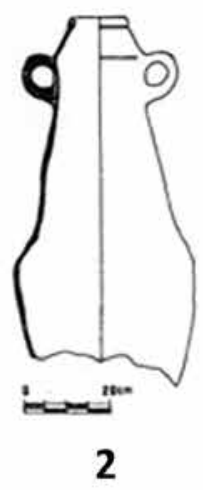

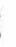
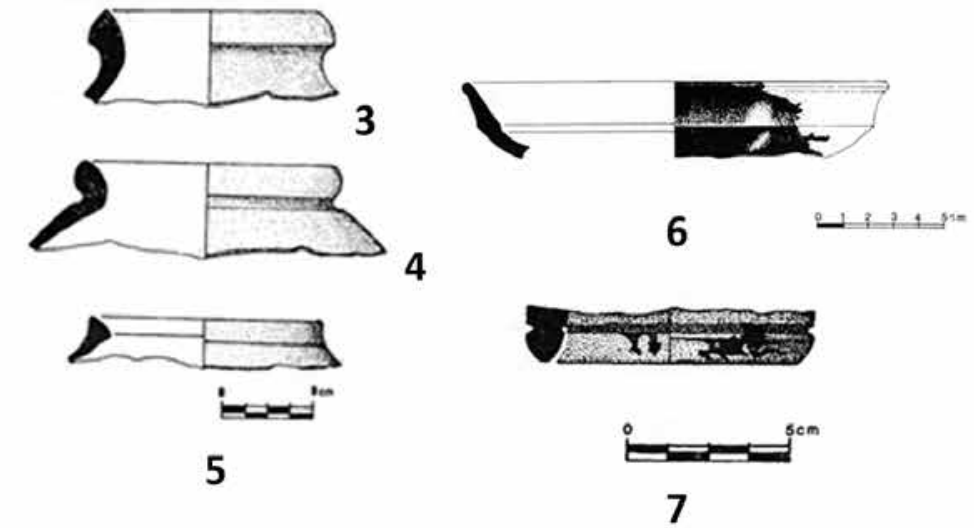

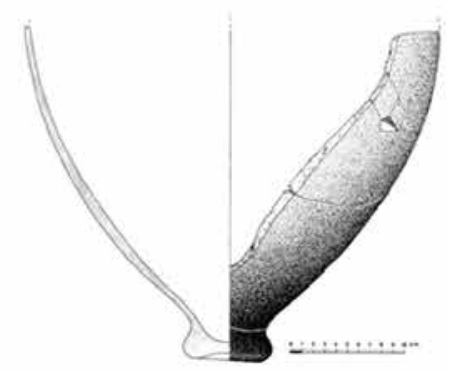

8

Figura 5. Ânforas: 1 - Neves I (seg. Maia, 1987); 2 a 5 - Neves II (seg. Maia, 1988). Cerâmica Ática: 6 - Neves I (seg. Maia, 1987); 7 - Neves II (seg. Maia \& Correa, 1985). Ânfora Grega: 8 - Monte Beirão (seg. Beirão, 1986). 
contexto em causa igualmente do século $\mathrm{V}$ a.n.e., ou quando muito dos inícios da centúria seguinte.

3.2. As esferas de consumo e o seu significado: uma aproximação.

O inventário acima ensaiado, com todas as dificuldades assinaladas e as eventuais lacunas que lhe possam ser apontadas, possibilita não obstante uma aproximação à distribuição de elementos de importação por contextos funcionais e permite, concomitantemente, uma primeira abordagem aos possíveis contextos sociais de uso desses elementos. Com efeito, uma análise de presenças/ausências dos vários materiais resenhados (Figura 6) resulta bastante expressiva denotando a existência, de resto expectável, de duas esferas de consumo perfeitamente diferenciadas - por um lado, os espaços domésticos e os prováveis contextos religiosos e, por outro, os contextos funerários.
Nos primeiros estão significativamente concentrados todos os exemplares de cerâmica grega inventariados, onde predominam em absoluto as $\mathrm{Ta}-$ ças Cástulo, recipientes tradicionalmente conotados com o consumo do vinho (Jiménez Ávila, 2008b, 124) e que se têm documentado com abundância em contextos ditos «Pós-Orientalizantes» da Extremadura, com particular destaque para o conjunto de Cancho Roano (Gracia Alonso, 2003), tendo-se vindo a associar frequentemente à prática de rituais de comensalidade (Celestino Pérez \& Cabrera Díez, 2008, 200-201), sejam eles em contextos religiosos ou em contextos mais propriamente conotados com a afirmação, manutenção e representação de laços sociais (Jiménez Ávila, 2007, 275).

No mesmo sentido aponta a presença, residual mas contextualmente expressiva, de contentores anfóricos de importação. Especialmente interessante é

\begin{tabular}{|c|c|c|c|c|c|c|c|c|c|c|}
\hline \\
\hline & & & 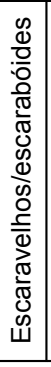 & 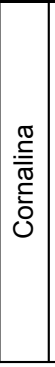 & 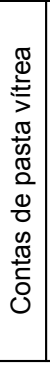 & 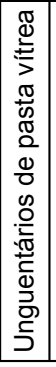 & 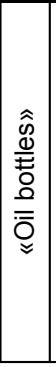 & 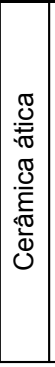 & 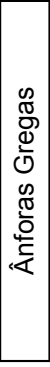 & 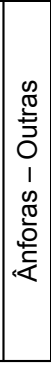 \\
\hline \multirow{4}{*}{ Domésticos } & Fernão Vaz & Beirão \& Correia, 1990; Correia \& Parreira, 2002 & & & $\bullet$ & & & $\cdot$ & & \\
\hline & Monte Beirão & Beirão, 1986 & & & & & & & $\cdot$ & \\
\hline & Neves II & Maia \& Maia, 1986; Maia, 1988 & & & & & & $\cdot$ & & $\cdot$ \\
\hline & Cabeço Redondo & Soares, 2012 & & & & & & $\bullet$ & & $\bullet$ \\
\hline \multirow{3}{*}{ Religiosos } & Neves I & Maia \& Maia, 1986; Maia, 1987 & & & $\bullet$ & & & $\cdot$ & & $\cdot$ \\
\hline & Corvo I & Maia \& Maia, 1986; Maia, 1988; 2008 & & & $\cdot$ & $\cdot$ & & $\cdot$ & & $?$ \\
\hline & Azougada & Gomes, 1990; Arruda, 1997; 2006 & & & $\cdot$ & & & $\bullet$ & & \\
\hline \multirow{12}{*}{ Funerários } & Fernão Vaz & Correia, 1993 & & & $\bullet$ & & & & & \\
\hline & Chada & Beirão, 1986 & & & $\cdot$ & & & & & \\
\hline & Fonte Santa & Beirão, 1986 & $\cdot$ & $\cdot$ & $\cdot$ & & & & & \\
\hline & Mealha Nova & Dias, Beirão \& Coelho, 1970 & $\bullet$ & $\bullet$ & $\bullet$ & & & & & \\
\hline & Herdade do Pêgo & Dias, Beirão \& Coelho, 1970 & & & $\cdot$ & & & & & \\
\hline & Pardieiro & Beirão, 1990 & $?$ & $\cdot$ & $\cdot$ & & & & & \\
\hline & Favela Nova & Dias \& Coelho, 1983 & $\bullet$ & & $\bullet$ & & & & & \\
\hline & Nora Velha & Arnaud, Martins \& Ramos, 1994; Soares \& Martins, 2013 & & & $\cdot$ & & & & & \\
\hline & Corte Margarida & Deus \& Correia, 2005 & $\cdot$ & & $\cdot$ & & & & & \\
\hline & Palhais & Santos et al., 2009 & $\bullet$ & & $\cdot$ & & $\cdot$ & & & \\
\hline & Carlota & Salvador Mateos \& Pereira, 2012 & & & & & $\bullet$ & & & \\
\hline & Vinha das Caliças 4 & Arruda et al., no prelo; Gomes, no prelo & $\cdot$ & • & $\cdot$ & & & & & \\
\hline
\end{tabular}

Figura 6. Elementos importados: distribuição e repartição funcional. 
a presença da ânfora de provável produção Sâmia de Monte Beirão, que corresponderá a um provável contentor vinário (cf. Arribas et al., 1987), que pode assim considerar-se mais uma evidência do destaque social assumido pelo consumo do vinho e dos seus derivados, em linha com o que ficou dito para os recipientes de produção ática antes comentados.

Para os restantes contentores anfóricos, a questão é menos evidente: as ânforas de Tipo Mañá-Pascual A4 costumam ser relacionadas com o transporte de preparados piscícolas, ao passo que os conteúdos das ânforas Tipo Pellicer B/C não estão ainda devidamente precisados. Independentemente desse grau de incerteza, o certo é que pode falarse da incorporação de produtos alimentares de importação, atestando uma capacidade aquisitiva que, por ser restrita, se torna ainda mais significante no contexto local e que deve, porventura, conotar-se também com práticas sociais muito específicas.

Com efeito, as evidências, embora ainda escassas, permitem defender a ideia de que estes (raros) elementos conotados com um comércio de longa distância foram incorporados, ao nível local, em práticas de comensalidade, de provável cariz ritualizado a julgar pela sua presença não só em âmbitos estritamente domésticos mas também em outros para os quais pode defender-se uma funcionalidade religiosa.

Recorde-se, a este propósito, um contexto especialmente expressivo identificado em Corvo I, onde se documenta a associação contextual entre uma estrutura de combustão estruturada e um espeto de ferro (Maia \& Maia, 1996, 87-88; Maia, 2008, 361), formalmente assimilável aos chamados assadores ou obeloi de bronze frequentemente presentes em contextos proto-históricos (Almagro Gorbea, 1974; Gamito, 1988; Armada Pita, 2005) e usualmente relacionados com o consumo de carne em contextos particulares, igualmente conotados com práticas comunais, da esfera da comensalidade (Jiménez Ávila, 2002; Armada Pita, 2005, 1263). A identificação destas realidades, espacialmente próximas ao que parece do contexto de recolha dos exemplares de cerâmica ática deste sítio, reforça a imagem da existência de uma área destinada à realização de banquetes.

As práticas de comensalidade, bem documentadas na Proto-História peninsular (Berrocal-Rangel 2004; Celestino Pérez \& Cabrera Díez, 2008; Armada Pita, 2008; Grau Mira, 2010), servem propósitos sociais muito concretos (Sardá Seuma, 2010), podendo no caso do interior baixo alentejano imaginar-se que estariam ligadas à manutenção de laços sociais entre os diversos pólos de uma malha de povoamento que, tudo o indica, seria constituída quase exclusivamente por pequenos núcleos abertos e dispersos na paisagem, dependentes pois para o seu funcionamento e a sua reprodução social de lógicas de entrosamento e de funcionamento em rede, na gestão e manutenção das quais o consumo comunal de alimentos em ocasiões assinaladas, de diversa natureza, poderão ter tido um papel destacado, constituindo também oportunidades para a ostentação da riqueza (relativa), justificando a incorporação de materiais exóticos (Grau Mira, 2010, 268-269).

Totalmente distinta é a fisionomia do perfil de importações atestada nos contextos funerários. Desde logo distinguem-se os elementos de adorno e/ou amuletos, com particular destaque para as contas de colar de pasta vítrea, que estando presentes em quantidades mais ou menos residuais em contextos domésticos e, especialmente, religiosos - destacando-se, ao que parece, o conjunto da Azougada (Gomes, 1990) -, são bastante mais expressivas, quer quantitativamente quer qualitativamente em contextos sepulcrais.

Os dados para valorizar o significado social destas peças são ainda reduzidos, mas reiterem-se as conclusões que podem extrair-se do caso da Vinha das Caliças 4 (Gomes, no prelo b): estes adornos parecem especialmente conotados com indivíduos femininos, de estatuto social plausivelmente elevado, estando de resto distribuídas de forma bastante desigual pelas diversas sepulturas.

Também para os elementos de cornalina, e com base nos dados da mesma necrópole, se pode indicar um padrão de utilização semelhante, embora ainda muito mais restrito. Idênticas considerações, por fim, se poderiam tecer para os amuletos de tipo egípcio, escaravelhos e/ou escarabóides, para os quais se reconheceu já um possível significado apotropaico no contexto das sociedades indígenas peninsulares (Padró i Parcerisa, 2002-2003).

A presença destes elementos de adorno em contextos funerários, para além de eventuais significados religiosos que não estamos em condições de restituir plenamente, parece resultar de uma lógica mais alargada de investimento no cenário da morte como espaço privilegiado de representação do status e de reforço das relações e da coesão social do grupo, materializada não apenas nos espólios, mas também nas complexas (e diversificadas) arquitec- 
turas presentes na região (Correia, 1993; Arruda, 2004; Santos et al., 2009; Salvador Mateos \& Pereira, 2012; Arruda et al., no prelo).

A sua introdução na indumentária e nos espólios dos defuntos, em particular nos do sexo feminino, deve entender-se como mais uma faceta a juntar a outras, como a presença de joalharia e de outros elementos de indumentária - fíbulas, fechos de cinturão - sugestivos de uma adesão a modelos de representação social supra-regionais, como ainda recentemente se enfatizou para contextos funerários do Alentejo Central (Mataloto, 2010-2011, 96).

A uma outra rubrica particular devem adscrever-se os recipientes destinados a óleos e perfumes (Gomes, no prelo c), nomeadamente as oil bottles, documentadas no interior apenas em contextos funerários, e o(s) recipiente(s) de pasta vítrea de Corvo $\mathrm{I}$, caso(s) isolado(s) proveniente(s), como disse, de um aparente contexto religioso. Como tive recentemente oportunidade de realçar (idem), o consumo deste tipo de substâncias parece, com efeito, ter respondido a pautas predominantemente rituais, tanto em ambientes religiosos como no contexto dos ritos funerários, devendo a este propósito salientarse a presença nas recém-descobertas necrópoles da região de Beja de taças de pé alto, frequentemente com decoração plástica, que indiciam a prática da queima de substâncias aromáticas (Santos et al., 2009; Arruda et al., no prelo).

A sua presença poderá constituir um indício mais de alterações nas pautas rituais, quer no culto quer no contexto funerário; estamos contudo tão mal informados no que a momentos anteriores diz respeito sobre estes dois aspectos concretos que dificilmente poderemos avaliar se aquilo a que assistimos é uma efectiva novidade, de introdução exógena ou - o que à luz dos dados anteriormente equacionados parece porventura mais provável - se trata de uma incorporação de produtos e seus respectivos contentores de origem forânea em práticas que pertencem a um fundo cultural eminentemente local.

\section{Considerações FINAIS}

À luz do que ficou dito nos parágrafos precedentes, parece possível, pois, e mesmo numa análise relativamente superficial como a que aqui ensaiei, extrair algumas conclusões de ordem geral sobre o contexto e significado dos elementos de importação analisados.

Desde logo parece-me importante a constatação circunstanciada da existência de esferas de consu- mo diferenciadas, não só pelas inferências que essa delimitação permite realizar sobre os contextos sociais de uso dos materiais importados mas também por sugerir com particular veemência que esses elementos foram incorporados em práticas eminentemente locais, servindo como um elemento mais na estruturação de um discurso destinado a projectar e reforçar a coesão social do grupo e a sua identidade partilhada, a par naturalmente do seu papel enquanto signos de estatuto.

Estes elementos, tão frequentemente imersos numa cultura material que evidencia sinais de arcaísmo e denuncia a perduração de modelos profundamente enraizados nas tradições locais, são de resto relativamente pouco abundantes. Essa restrição quantitativa poder-se-á ler como um sintoma de relativa periferalidade, é certo, mas alternativa ou complementarmente pode também entender-se como uma marca identitária específica destas comunidades interiores.

Torna-se, pois, evidente, e independentemente de matizes sub-regionais e cronológicos que importaria caracterizar com maior detalhe no futuro através de análises contextuais mais detalhadas, que existe uma estratégia comum de adopção selectiva de elementos exógenos, incorporados como mais um recurso na construção de discursos sociais e identitários de âmbito local, que ganham um sentido especial num contexto sociopolítico fragmentado em que a representação de cada micro-grupo social - seja ele de base familiar, de base locacional ou outra - nas relações com os seus congéneres se reveste de tanta importância como a representação do macro-grupo social - e, se quisermos, cultural em face dos grupos vizinhos e mesmo no quadro mais vasto das redes de intercâmbio e circulação que unem o Sudoeste peninsular ao mundo mediterrâneo.

\section{REFERÊNCIAS BIBLIOGRÁFICAS}

Almagro Gorbea, M. (1974), "Los asadores de bronce del Suroeste peninsular", Revista de Archivos, Bibliotecas y Museos, LXXVII.1, 351-395. Almagro Gorbea, M. (1977), El Bronce Final y el Periodo Orientalizante en Extremadura, Madrid.

Almagro Gorbea, M. e Torres Ortiz, M. (2009), "Los escarabeos fenicios de Portugal. Un estado de la cuestión”, Estudos Arqueológicos de Oeiras, 17, 521-554.

Almeida, J. F. de e Araújo, L. M. de (2009), "Es- 
caravelhos egípcios em Portugal”, Cadmo, 19, 97-130.

Antunes, A. S. (2008), “"Castro» da Azougada (Moura, Portugal): percursos do PósOrientalizante no Baixo Guadiana", Sidereum Ana I: El río Guadiana en Época PostOrientalizante (Jiménez Ávila, J., ed.), Madrid, 327352.

Antunes, A. S. (2009), "«Castro» da Azougada (Moura, Portugal): sacralidade e dinamismo comercial no Baixo Guadiana durante o PósOrientalizante", Santuarios, oppida y ciudades: Arquitectura sacra en el origen y desarrollo urbano del Mediterráneo occidental (Mateos Cruz, P., Celestino Pérez, S., Pizzo, A., e Tortosa, T., coords.), Madrid, 131-152.

Antunes, A. S. (2010), Um conjunto cerâmico da Azougada. Em torno da Idade do Ferro PósOrientalizante da margem esquerda do Baixo Guadiana, Lisboa.

Armada Pita, X. L. (2005), “Asadores de la Península Ibérica y cuestión orientalizante: un ensayo de síntesis”, El Período Orientalizante (Celestino Pérez, S. e Jiménez Ávila, J., coords.), Madrid, 1249-1267.

Armada Pita, X. L. (2008), “¿Carne, drogas o alcohol? Calderos y banquetes en el Bronce Final de la Península Ibérica”, Cuadernos de Prehistoria y Arqueología de la Universidad de Granada, 18, 125-162.

Arnaud, J. M., Martins, A., e Ramos, C. (1994), "Necrópole da Nora Velha (Ourique). Informação da $1^{a}$ Campanha de Escavação”, V Jornadas Arqueológicas da Associação dos Arqueólogos Portugueses, Lisboa, 199-210.

Arribas, A., Trías, M. G., Cerdá, D. e Hoz, J. de (1987), El Barco de El Sec (Costa de Calviá, Mallorca). Estudio de los Materiales, Mallorca.

Arruda, A. M. (1997), As Cerâmicas Áticas do Castelo de Castro Marim no quadro das exportações gregas para a Península Ibérica, Lisboa.

Arruda, A. M. (19992000), Los Fenicios en Portugal. Fenicios y mundo indígena en el centro y sur de Portugal (siglos VIIIVI a.C.), Barcelona.

Arruda, A. M. (2001), “A Idade do Ferro PósOrientalizante no Baixo Alentejo”, Revista Portuguesa de Arqueologia, 4:2, 207291.

Arruda, A. M. (2004), "Necrópoles protohistóricas do sul de Portugal: o mundo oriental e orientalizante”, El mundo funerario, Actas del III
Seminario Internacional sobre Temas Fenícios, Alicante, 2004 (González Prats, A., ed.), Alicante, 457-494.

Arruda, A. M. (2005a), "Orientalizante e PósOrientalizante no Sudoeste Peninsular. Geografias e Cronologias", El Período Orientalizante (Celestino Pérez, S. e Jiménez Ávila, J., coords.), Madrid, 277-304.

Arruda, A. M. (2005b), "O I ${ }^{\mathrm{Q}}$ Milénio a.n.e. no Centro e no Sul de Portugal: leituras possíveis no início de um novo século”, O Arqueólogo Português, IV, 23, 91-56.

Arruda, A. M. (2006), "Cerâmicas Gregas encontradas em Portugal”, Vasos Gregos em Portugal. Aquém das Colunas de Hércules (Pereira, M. H. da R., coord.), Lisboa, 135-140.

Arruda, A. M., Barbosa, R., Gomes, F. B. e Sousa, E. (no prelo), "A necrópole da Vinha das Caliças (Beringel, Beja, Portugal)”, Sidereum Ana III - El Río Guadiana en Época Tartésica (Jiménez Ávila, J., ed.), Madrid.

Arruda, A. M., Barros, P., e Lopes, V. (1998), “Cerâmicas áticas de Mértola”, Conimbriga, 37, 122-149.

Arruda, A. M. e Celestino Pérez, S. (2009), "Arquitectura Religiosa en Tartessos”, Santuarios, oppida y ciudades: Arquitectura sacra en el origen y desarrollo urbano del Mediterráneo occidental (Mateos Cruz, P., Celestino Pérez, S., Pizzo, A., e Tortosa, T., coords.), Madrid, 29-77.

Beirão, C. de M. (1986), Une Civilisation Protohistorique du Sud du Portugal (Ier Âge du Fer), Paris.

Beirão, C. de M. (1990), "Epigrafia da I Idade do Ferro do Sudoeste da Península Ibérica. Novos dados arqueológicos”, Estudos Orientais, I, 107-118.

Beirão, C. de M. e Correia, V. H. (1991), “A cronologia do povoado de Fernão Vaz”, Conimbriga, 30, 5-11.

Belén, Ma . (2006), “Ánforas de los siglos VI-IV A.C. en Turdetania”, Spal, 15, 217-246.

Berrocal-Rangel, L. (2004), "Banquetes y rituales colectivos en el suroeste peninsular", Cuadernos de Prehistoria y Arqueología de la Universidad Autónoma de Madrid,30, 105-119.

Calado, D. e Gomes, M. V. (2006), "Quinta da Queimada (Lagos): a necrópole da II Idade do Ferro”, Revista Portuguesa de Arqueologia, 9:2, 171185. 
Calado, M., Mataloto, R. e Rocha, A. (2007), "Povoamento ProtoHistórico na Margem Direita do Regolfo do Alqueva (Alentejo, Portugal)", Arqueologia de la Tierra. Paisajes rurales de la protohistoria peninsular (Rodríguez Díaz, A. e Pavón Soldevilla, I., eds.), Cáceres, 129-179.

Calado, M. e Mataloto, R. (2008), "O PostOrientalizante da Margem Direita do Regolfo do Alqueva (Alentejo Central)", Sidereum Ana I - El Río Guadiana en Época Post-Orientalizante (Jiménez Ávila, J., ed.), Madrid, 185-217.

Celestino Pérez, S. (1995), "El Período Orientalizante en Extremadura”, Extremadura Arqueológica, IV, 67-89.

Celestino Pérez, S. (2005), "El Período Orientalizante en Extremadura y la colonización tartésica del interior”, El Período Orientalizante (Celestino Pérez, S. e Jiménez Ávila, J., coords.), Madrid, 767-786.

Celestino Pérez, S. (2008), "El reflejo del fenicio en el interior peninsular", Nuevas Perspectivas II - La Arqueología Fenicia y Púnica en la Península Ibérica (Vita, J. P. e Zamora, J. Á., eds.), Barcelona, 25-38.

Celestino Pérez, S. e Cabrera Díez, A. (2008), "El banquete privado y el banquete comunal en el santuario de Cancho Roano", Cuadernos de Prehistoria y Arqueología de la Universidad de Granada, 18, 189-215.

Correia, V. H. (1993), "As necrópoles da Idade do Ferro do Sul de Portugal: Arqueologia e rituais”, Trabalhos de Antropologia e Etnologia, 33:34, 351370.

Correia, V. H. e Parreira, R. (2002), Cola. Circuito Arqueológico, Lisboa.

Deus, M. de e Correia, J. (2005), "Corte Margarida. Mais uma necrópole orientalizante no Baixo Alentejo", El Período Orientalizante (Celestino Pérez, S. e Jiménez Ávila, J., coords.), Madrid, 615-618.

Dias, M ${ }^{\mathrm{a}}$. M. A., Beirão, C. de M., e Coelho, L. (1970), "Duas necrópoles da Idade do Ferro no Baixo Alentejo: Ourique”, O Arqueólogo Português, 3:3, 175-219.

Dias, Mª. M. A. e Coelho, L. (1983), "Objectos arqueológicos dum túmulo de incineração da necrópole proto-histórica da Herdade da Favela Nova (Ourique)", O Arqueólogo Português, IV:1, 197-206.

Fabião, C. (2001a), "O povoamento do Sudoeste peninsular na segunda metade do I milénio a.C.: continuidades e rupturas”. Entre Celtas e Iberos (Berrocal-Rangel, L. e Gardes, P., eds.), Madrid, 227-246.

Fabião, C. (2001b), "Importações de origem mediterrânea no interior do sudoeste peninsular na segunda metade do I Milénio a.C.: materiais da Cabeça de Vaiamonte, Monforte", Os Púnicos no Extremo Ocidente, Lisboa, 197-228.

Gamito, T. J. (1988), "Os obeloi de bronze do Sudoeste peninsular: seu contexto e interpretação sócioideológica”, Actas del 1er. Congreso Peninsular de Historia Antigua (Pereira Menaut, G., ed.), Santiago de Compostela, 329-339.

Gomes, F. B. (2012), Aspectos do Sagrado na Colonização Fenícia, Lisboa.

Gomes, F. B. (no prelo a), “The West Writes Back: cultural contact and identity discourses in Southern Portuguese Late Bronze Age and Early Iron Age", The Mediterranean Mirror. Cultural contacts in the Mediterranean Sea between 1200 and 750 B.C., Mainz, 346-362.

Gomes, F. B. (no prelo b), "Mediterranean imports in "Post-Orientalizing" funerary contexts of southern Portugal: some remarks on consumption, peripherality and cultural identity", Actas del XVIII Congreso Internacional de Arqueología Clásica, Mérida.

Gomes, F. B. (no prelo c), "As "oil bottles” de tipo fenício no território português e o consumo de substâncias aromáticas”, O Arqueólogo Português, V:3.

Gomes, M. V. (1990), “O Oriente no Ocidente. Testemunhos iconográficos na Proto-história do Sul de Portugal: smithing gods ou deuses ameaçadores", Estudos Orientais, I, 53-106.

Gonçalves, A. P. e Soares, A.M.M. (2010), “As "contas de colar» dos Ratinhos - I. As contas em pedra, análise por Difracção de Raios X”, $O$ Castro dos Ratinhos (Barragem do Alqueva, Moura). Escavações num povoado proto-histórico do Guadiana, 2004-2007, Lisboa, 389392.

Gonçalves, A. P., Soares, A.M.M., Silva, A.C., y Berrocal-Rangel, L. (2011), "Stone Beads from Late Bronze Age and Early Iron Age Settlements from South-Western Portugal: Analyses by X-Ray Diffraction". Proceedings of the 37th International Symposium on Archaeometry (13th-16th May 2008, Siena, Italy). Part 2 (Turbanti-Memmi, I., ed.), Heidelberg, 227-231. Gracia Alonso, F. (2003), "Las cerâmicas áticas del 
palacio-santuario de Cancho Roano”, Cancho Roano VIII, Los Materiales Arqueológicos I (Celestino Pérez, S., ed. cient.), Mérida, 23-194.

Grau Mira, I. (2010), "Vajillas mediterráneas y prácticas de comensalidad en el área central de la Contestania Ibérica”, De la cuina a la taula. IV Reunió d'Economia en el Primer Milleni $A C$ (Mata, C., Pérez Jordá, G., e Vives-Ferrándiz Sánchez, J., eds.), Valencia, 263-270.

Guerrero Ayuso, V. (1991), "El Palacio-Santuario de Cancho Roano (Badajoz) y la comercialización de las ánforas fenicias indígenas”, Rivista $d i$ Studi Fenici, XIX:1, 49-82.

Jiménez Ávila, J. (1997), "Cancho Roano y los Complejos Monumentales Post-Orientalizantes del Guadiana”, Complutum, 8, 141-159.

Jiménez Ávila, J. (1999), "Los objetos de vidrio procedentes del yacimiento de Pajares: estudio preliminar", El yacimiento Protohistórico de Pajares, Villanueva de la Vera, Cáceres. 1. Las Necrópolis y el Tesoro Áureo (Celestino Pérez, S., ed.), Mérida, 139-153.

Jiménez Ávila, J. (2002), La toréutica orientalizante en la Península Ibérica, Madrid.

Jiménez Ávila, J. (2002-2003), "Estructuras tumulares en el Suroeste ibérico. En torno al fenómeno tumular en la Protohistoria peninsular", Boletín de la Asociación Española de Amigos de la Arqueología, 42, 81-118.

Jiménez Ávila, J. (2003), "Los objetos de pasta vítrea de Cancho Roano", Cancho Roano VIII, Los Materiales Arqueológicos I (Celestino Pérez, S., ed. cient.), Mérida, 263-291.

Jiménez Ávila, J. (2004), "La necrópolis de El Jardal (Herrera del Duque, Badajoz): Elementos para una revisión Cronológica de las Necrópolis de la $1^{\mathrm{a}}$ Edad del Hierro del Sur de Portugal”, Actas do II Encontro de Arqueologia do Sudoeste, Faro, 106-114.

Jiménez Ávila, J. (2007), "The Greek Trade in Extremadura, $6^{\text {th }}-4^{\text {th }}$ centuries B.C.", Vipasca, Arqueologia e História, 2:2, 269-283.

Jiménez Ávila, J., ed. (2008a), Sidereum Ana I. El río Guadiana en época post-orientalizante, Madrid.

Jiménez Ávila, J. (2008b), "El Final del Hierro Antiguo en el Guadiana Medio", Sidereum Ana I. El río Guadiana en época post-orientalizante (Jiménez Ávila, J., ed.), Madrid, 101-134.

Jiménez Ávila, J. e Ortega Blanco, J. (2008), “El poblamiento en llano del Guadiana Medio du- rante el período post-orientalizante", Sidereum Ana I. El río Guadiana en época post-orientalizante (Jiménez Ávila, J., ed.), Madrid, 251282.

Maia, Mª . (1987), "Dois larnakes da Idade do Ferro do Sul de Portugal”, Veleia, 23, 223-242.

Maia, M"a . (1988), "Neves II e a "facies» cultural de Neves Corvo", Arquivo de Beja, 2:3, 23-42.

Maia, Ma . (2008), "Reflexões sobre os complexos arquitectónicos de Neves-Corvo, na região central do Baixo Alentejo, em Portugal”, Sidereum Ana I. El río Guadiana en época post-orientalizante (Jiménez Ávila, J., ed.), Madrid, 353364.

Maia, Mª . e Correa, J. A. (1985), "Inscripción en escritura tartéssica (o del SO) hallada en Neves (Castro Verde, Baixo Alentejo) y su contexto arqueológico", Habis, 16, 243-274.

Maia, Mª . e Maia, M. (1986), Arqueologia da área mineira de Neves-Corvo, Castro Verde.

Maia, Ma . e Maia, M. (1996), “Arqueologia do couto mineiro de Neves Corvo”, Mineração do Baixo Alentejo (Rego, M., ed.), Castro Verde, 83-93.

Martín de la Cruz, J. C. (2004), "Colgantes y cuentas de cornalina procedentes de Andalucía Occidental", Revista de Prehistoria, 3, 7-47.

Martín de la Cruz, J. C., Vera Rodríguez, J. C., Gavilán Cevallos, B., e Perlines Benito, $\mathrm{M}^{\mathrm{a}}$. (2005), "Un colgante de cornalina de manufactura oriental procedente de la provincia de Córdoba”, El Período Orientalizante (Celestino Pérez, S. e Jiménez Ávila, J., coords.), Madrid, 503-509.

Mataloto, R. (2004), Um «monte» da Idade do Ferro na Herdade da Sapatoa: ruralidade e povoamento no I milénio a.C. do Alentejo Central, Lisboa.

Mataloto, R. (2008), "O Pós-Orientalizante que nunca o foi... Uma comunidade camponesa na Herdade da Sapatoa (Redondo, Alentejo Central)", Sidereum Ana I. El río Guadiana en época post-orientalizante (Jiménez Ávila, J., ed.), Madrid, 219-249.

Mataloto, R. (2009), “Através dos campos: arquitectura e sociedade na Idade do Ferro alto alentejana”, L'espai domèstic i l'organització de la societat a la protohistòria de la Mediterrània occidental (Ier millenni $a C$ ) (Belarte, $\mathrm{M}^{\mathrm{a}}$. C., ed.), Barcelona, 279-298.

Mataloto, R. (2010-2011), “Os Senhores da Terra: necrópoles e comunidades rurais do território alto alentejano nos sécs. VI-V aC", Arqueologia 
e História, 60-61, 77-100.

Mataloto, R. (2012), "Os Senhores e as Serras: o final da Idade do Bronze no Alentejo Central”, Sidereum Ana II - El río Guadiana en el Bronce Final (Jiménez Ávila, J., ed.), Madrid, 185-213.

Orsingher, A. (2010), "Le oil bottle fenicie: analisi dei contesti e considerazione crono-tipologiche”, Sardinia, Corsica et Baleares Antiquae, VIII, 37-69.

Padró i Parcerisa, J. (2002-2003), "Una función apotropaica de los amuletos de tipo egipcio en el mundo prerromano hispano", Cuadernos de Prehistoria y Arqueología castellonense, 23, 247-250.

Pellicer, M. (1978), “Tipología y cronología de las ánforas prerromanas del Guadalquivir según el Cerro Macareno (Sevilla)”, Habis, 9, 365-400.

Ramon Torres, J. (1995), Las ánforas fenício-púnicas del Mediterráneo Central e Occidental, Barcelona.

Rocha, L., Duarte, C., e Pinheiro, V. (2005), “A necrópole da $1^{a}$ Idade do Ferro do Monte da Têra, Pavia (Portugal): dados das últimas intervenções”. El Periodo Orientalizante (Celestino Pérez, S. e Jiménez Ávila, J., coords.), Madrid, 605-614.

Rouillard, P., Paixão, A. C., Villanueva-Puig, M. C., e Durand, J. L. (1988-9), "Les vases grecques d'Alcácer do Sal”, O Arqueólogo Português, 4:6-7, 43-108.

Sáez Romero, A. (2008), La producción cerámica en Gadir en época tardopúnica (siglos -III/ $-I$ ), Oxford.

Salvador Mateos, R. e Pereira, J. A. (2012), “A «Necrópole» da Carlota (São Brissos, Beja) no contexto cultural da $\mathrm{I}^{\mathrm{a}}$ Idade do Ferro do Baixo Alentejo: dados preliminares", Actas do V Encontro de Arqueologia do Sudoeste Peninsular (Deus, M. de, ed.), Almodôvar, 317-330.

Santos, F., Antunes, A. S., Grilo, C., e Deus, M. de (2009), "A necrópole da I Idade do Ferro de Palhais (Beringel, Beja). Resultados preliminares de uma intervenção de emergência no Baixo Alentejo”, IV Encuentro de Arqueología del Suroeste Peninsular, Huelva, 746-804.

Sardá Seuma, S. (2010), "El giro comensal: nuevos temas y nuevos enfoques en la Protohistoria peninsular", Herakleion, 3, 37-65.

Soares, R. M. (2012), O Cabeço Redondo. Um edifício da Idade do Ferro Pós-Orientalizante na Herdade do Metum (Moura), Tese de Mestrado em Arqueologia apresentada à Faculdade de Letras da Universidade de Lisboa, Edição policopiada.

Soares, R. M. e Martins, A. (2013), “A necrópole da Nora Velha (Ourique). Novos dados e interpretações 20 anos após a sua escavação", Arqueologia em Portugal. 150 Anos (Arnaud, J. M., Martins, A. e Neves, C., eds.), Lisboa, 661-669. 